\title{
Diakonie ve veřejné sféře - dcera nebo sestra církve? Církev a diakonie mezi oddělením a přiblížením Karel Šimr
}

Otázka po vztahu církve a diakonie je v ekumenické šíri v posledních desetiletích zodpovídána převážně v rámci pastorálně-teologické teorie konstitutivních znaků církve. Diakonie je zde spolu s martyrií a leitourgií (případně koinonií) chápána jako jeden z prvků, jimiž se církev uskutečňuje. ${ }^{1}$ Budeme-li však v tomto př́spěvku pojmem diakonie označovat empirickou skutečnost dnešních podob církvemi zřizované sociální práce ve veřejné sféře $\mathrm{v}$ rámci struktur sociálního státu, pak vzniká otázka, zda je uvedenou teorií možné tuto praxi dostatečně postihnout. Toto rozpoznání nikterak nezpochybňuje význam „všeobecného diakonátu“ věřících ani úsilí o obnovu základního diakonického sebevědomí církve coby místní křestanské obce. Přes všechno oprávněné hledání diakonické církve ovšem zůstává výzva, jak historicky utvářenou dominantní podobu dnešní diakonické práce církví v její rozporuplnosti adekvátně teoreticky uchopit a na základě toho určit její vztah k církvi i společnosti. Ve svém uvažování se o to chci pokusit ve třech krocích - historickou reminiscencí, sociologickou analýzou a teologickým zhodnocením.

\section{Problém dvojí příslušnosti}

Nejprve se na několika př́kladech z protestantského prostředí (i z toho důvodu, že právě v něm můžeme v polovině 19. stol. nalézt počátky dnešní podoby organizované diakonické a charitativní práce) pokusím ukázat, že diakonie v moderní společnosti vzniká vlastně již mimo institucionalizovanou církev.

Začněme pohledem do reformace, která velkým dílem přispěla k přenesení odpovědnosti za sociální oblast na světskou vrchnost (výrazněji k tomu tendovala reformace luterská, reformovaná větev se pokoušela vázat zodpovědnost za sociální otázky více na sbor, např. snahou o obnovu diakonátu v rámci čtverého církevního úřadu, ovšem i zde nakonec převážilo uplatnění principu delegace diakonických úkoli̊ na magistráty). Žretelně můžeme toto napětí sledovat v reformních snahách Martina Bucera ve Štrasburku. Když zde v roce 1523 začal se svou reformní činností, všechnu sociální odpovědnost již na svých bedrech neslo vedení města, a sborový diakonát se tak jevil jako přebytečný. Bucer, pro něhož církev existovala jak v podobě vyznávajícího společenství, tak ve formě křest̉anské společnosti, ovšem považoval za důležité zakotvit sociální pomoc v obou naznačených rovinách. Proto usiloval o začlenění představitelů městské sociální péče i do církevní struktury a o jejich jmenování diákony v biblickém chápání. ${ }^{2}$ Bucerův pokus zakotvit

1 Viz např. Markus LEHNER, Prokrustovo lože - systematizace pastorálky, Teologické texty 5/1996, s. 149.

2 Srov. Gerhard K. SCHÄFER - Volker HERMANN, Geschichtliche Entwicklungen der Diakonie von der Alten Kirche bis zur Gegenwart 
diakonickou práci jak v instituční církvi, tak ve světských strukturách společnosti se ovšem prosadit nepodařilo. Do budoucna se pak již naznačený problém dvojí perspektivy organizovaného díla pomoci ještě více vyostřuje, protože jak pro sféru náboženství, tak pro stát je obtížné připustit dvojí loajalitu svého konání. ${ }^{3}$ Uvedený poznatek nevyjadřuje kritiku nových podob sociální pomoci ve společnosti, pouze vyslovuje otázku či výzvu diakonické odpovědnosti církve.

Jestliže reformace tvoří spíše prehistorii současné situace diakonie ve veřejné sféře, konkrétní počátky její dnešní podoby spojujeme s působením německého teologa a zakladatele tzv. Vnitřní misie Johanna Hinricha Wicherna v Německu polovině 19. stol. Wichern ve své době reagoval na sociální důsledky průmyslové revoluce. Jeho cílem bylo křestansky odpovědět na sociální i duchovní nouzi obyvatelstva. Šlo mu skutečně o vnitřní misii německého národa, tedy o jeho celkovou rechristianizaci, přičemž sociální pomoc chápal jako její nedílnou součást. Ani zde však nemůžeme hovořit o církevní diakonické práci v přesném slova smyslu. Wichern nezakládá Vnitřní misii uvnitř institucionální církve, ale na bázi svobodného spolkového života. Tuto občanskou diakonii odlišuje - v duchu luterského učení o dvou regimentech - od diakonie církevní, která podle něj měla spočívat především $\mathrm{v}$ obnově sborového diakonátu. Vývoj se ovšem ubíral, a to nejen v Německu a nejen v evangelickém prostředí, spíše cestou rozvoje diakonie ve veřejné sféře. $\mathrm{K}$ posílení tohoto trendu dojde zejména s rozvojem sociálního státu po 2 . světové válce. $\mathrm{K}$ formálnímu spojení diakonické práce s instituční církví dochází u našich západních sousedů poprvé násilně během nacistické éry. Po válce nově vzniklé oficiálně církevní Evangelické pomocné dílo a svobodná Vnitřní misie pokračují paralelně a v roce 1957 dochází $\mathrm{k}$ jejich sloučení. Proces fůze ovšem vrcholí až v roce 1975 ustavením Diakonického díla Evangelické církve v Německu. ${ }^{4}$

Podobný vývoj můžeme sledovat také v našem kontextu na vývoji Diakonie Českobratrské církve evangelické. Ta vzniká díky uvolnění politické situace $\mathrm{v}$ měsících krátce před převratem $\mathrm{v}$ roce 1989 takříkajíc od stolu iniciativou tehdejšího synodního kurátora Miloše Lešikara, a to bez hlubšího zakotvení v církvi. Ačkoli zde bylo vždy přítomno i vědomí sounáležitosti obou institucí, první roky vývoje organizace jsou spíše dokladem snahy o získání co největší autonomie na církvi, která je vedením vnímána jako potřebný faktor pro rozvoj práce ve společnosti. Dokladem určitého obratu jsou na přelomu tisíciletí slova Zdeňka Bárty o tom, že „desetiletá postupná inkorporace Diakonie do těla církve a následná adopce Diakonie církví i po stránce právní byly správné kroky dobrým směrem“. ${ }^{5}$ Tímto vyjádřením naráží na vznik Řádu diakonické práce, jednoho ze souboru církevních řádů a zřízení, který začleňuje Diakonii do církevní struktury, pokouší se integrovat diakonii sborovou a instituční a vytvárí nástroje pro vzájemnou kooperaci. Ovšem hovořit o jakémsi organickém začlenění Diakonie do těla církve by bylo i zde vzhledem $\mathrm{k}$ realitě poněkud nadnesené. ${ }^{6}$

im Überblick, in: Studienbuch Diakonik, Band 1, ed. Volker HERRMANN - Martin HORSTMANN, Neukirchen-Vluyn: Neukirchener Verlag, 2006, s. 150.

3 Srov. Heinz SCHMIDT, Prägende geschitliche Erfahrungen der Diakonie in Deutschland, in: Das Geschenk der Solidarität. Chancen und Herausforderungen der Diakonie in Frankreich und Deutschland, Fritz LIENHARD - Heinz SCHMIDT, Heidelberg: Universitätsverlag Winter, 2006, s. 70-72.

4 Srov. např. Gerhard K. SCHÄFER - Volker HERMANN, Geschichtliche Entwicklung der Diakonie von der Alten Kirche bis zur Gegenwart im Überblick, s. 155-165.

5 Zpráva Diakonie ČCE za rok 1999, Archiv Diakonie ČCE.

6 Viz Karel ŠIMR, Církevní, nebo světská diakonie?, Caritas et veritas 2/2016, s. 284-298. 


\section{Náboženství a diakonie v moderní společnosti}

V novodobém vývoji diakonie můžeme tedy pozorovat jak tendence $\mathrm{k}$ větší autonomii diakonie a církve, tak snahy o jejich opětovné hlubší sepětí. Problém jejich vztahu ovšem úzce souvisí s obecnou situací náboženství v moderní společnosti.

Viděli jsme, že reformátoři mohli s více či méně klidným svědomím delegovat diakonickou odpovědnost na struktury světské moci, protože žili v dosud nepř́liš rozlišené křestanské společnosti, $v$ níž oblast náboženská a světská spadaly víceméně vjedno. Jestliže jsme např. spor mezi Bucerem a štrasburským magistrátem mohli vnímat jako projev kompetenčního konfliktu mezi církví a světskou vládou (jakýsi spor o „diakonickou investituru“), v moderní společnosti již půjde o mnohem zásadnější napětí v důsledku funkcionální diferenciace. Tento proces podrobně popisuje Niklas Luhmann $\mathrm{v}$ rámci teorie sociálních systémů. Vedle náboženství tak v rámci společnosti vznikají další samostatné sociální systémy jako politika, zdravotnictví, právo nebo vzdělání. Tyto systémy se řídí vlastními binárními kódy ( $\mathrm{v}$ př́ípadě náboženství např. transcendence/imanence) a mají odlišnou funkci. Podle Dierka Baeckera mủžeme v současné společnosti dokonce hovořit také o samostatném systému sociální pomoci, založeném na rozhodnutí o pomoci či nepomoci. ${ }^{8} \mathrm{~A}$ to pochopitelně diakonii, která se $\mathrm{v}$ této perspektivě podílí jak na systému náboženství, tak na systému sociální pomoci, staví do komplikované situace.

Vyhroceně formulováno: $\mathrm{O}$ jakém církevním rozměru diakonie je možné mluvit, když konkrétní práci vykonávají - aspoň v sekularizovanějších oblastech Čech - ve valné většině lidé bez osobní vazby $\mathrm{k}$ církvi, kteří jsou placeni $\mathrm{z}$ veřejných peněz a řídí se státem určenými standardy? Postačí $\mathrm{k}$ „církevnosti“ diakonie skutečnost, že jde o organizaci církví zřizovanou, případně umístění nástěnek $\mathrm{s}$ biblickými citáty či křiži na zdech $\mathrm{v}$ jejích zařízeních? A postoupíme-li dále $\mathrm{k}$ oblasti pastorace, není pozornost $\mathrm{k}$ duchovním potřebám a nabídka duchovních aktivit (v lepších případech) standardem i v sekulárních zařízeních (kaplani v nemocnicích, bohoslužby místních církví $\mathrm{v}$ domovech důchodců apod.)?

Nabízí se popsat současný stav diakonie v souvislosti teorie sekularizace. Ta určovala hlavní proud myšlení až do druhé poloviny 20. stol., dnes ovšem získává vážné trhliny. Zdá se, že „odnáboženštění není nezbytnou komponentou modernity a že jeho průvodní jevy jsou teritoriálně omezeny víceméně na západní Evropu. Navíc i v našem kulturním prostoru můžeme pozorovat pozvolné projevy deprivatizace náboženství a, jak si všímá Grace Davie, také přibývání zájmu o „postmaterialistické hodnoty" $\mathrm{v}$ souvislosti s tím, jak společnost postupuje v rámci druhé fáze modernizace od industriální ekonomiky $\mathrm{k}$ hospodaření založenému na službách, spojenému s dưrazem na kvalitu života. ${ }^{9}$

Sám Luhmann, jehož př́stup se pokoušíme zužitkovat $\mathrm{v}$ teorii diakonie, ve svém posledním díle, věnovaném sociologii náboženství (v roce 2000 posmrtně vydané Náboženství společnosti), považuje pojem sekularizace za problematický a sporný. Podle něj lze hovořit o deinstitucionalizaci (v našem kontextu tedy zejména o „odcírkevnění) náboženství, ale nikoli o tom, že by ztratilo společenskou relevanci. Fenomény, které jsme si zvykli souhrnně označovat jako sekularizaci, navrhuje proto přesněji popisovat právě funkcionální diferenciací. ${ }^{10}$ Náboženství se podle Luhmanna nachází ve stavu strukturálních nekompatibilit s moderní funkcionálně diferencovanou spo-

Více Karel ŠIMR, Diakonie v perspektivě teorie sociálních systémů, Studia theologica 1/2016, s. 81-95.

Srov. Dirk BAECKER, Soziale Hilfe als Funktionssystem der Gesellschaft, Zeitschrift für Soziologie 2/1994, s. 93-110.

Srov. Grace DAVIE, Výjimečný př́pad Evropa: podoby víry v dnešním světě, Brno: CDK, 2009, s. 184-185.

0 Srov. Niklas LUHMANN, Die Religion der Gesellschaft, Frankfurt am Main: Suhrkamp, 2000, s. 126. 
lečností a hledání nových možnosti napojení na ni. Tato nová situace má své možnosti i omezení. ${ }^{11}$ Mezi výhody patří např́klad skutečnost, že z exkluze ze systému náboženství již nevyplývá - jako tomu bylo ve středověku - exkluze i z dalších společenských systémů a naopak. Větší autonomie náboženského systému tedy představuje větší „evoluční výhodu“ a možnost inkluze pro ty, kdo jinými společenskými systémy „propadli““. ${ }^{12} \mathrm{~A}$ to je velká výzva právě pro diakonii.

Co je tedy podle Luhmanna charakteristické pro postavení křestanství v západní funkcionálně diferencované společnosti? Je vystaveno pozorování jiných společenských subsystémů s odlišným rozlišováním. Luhmann se ptá, „jak náboženský systém reaguje, když má trvale odpovídat na otázky, které sám nepoložil“1.13 A odpovídá, že zjevně skrze organizaci: „Otázky víry se stávají otázkami rozhodování. ${ }^{\text {"4 }} \mathrm{Od}$ pozdního středověku můžeme pozorovat proces, v němž nabývá na významu církevní struktura. V teologické reflexi tomu odpovídá rostoucí důraz na eklesiologii. Tento akcent na církevní instituci vnímanou jako „pevný hrad“ křestanství ve světě ovšem posiluje tendence $\mathrm{k}$ vyloučení církve ze společnosti. Joachim Matthes např́klad diskutuje vyhrocenou tezi o emigraci církve ze společnosti. ${ }^{15}$ Nejen společnost je podle něj „odcírkevněna“, ale také církev “odspolečenštěna“, to znamená, že „už ve své vnitřní skladbě nereprezentuje formy a struktury společnosti“. ${ }^{16}$ Zatímco sekularizaci můžeme s Luhmannem chápat vlastně pozitivně jako osvobození křestanství od různých druhotných společenských funkcí vedoucí k soustř̌edění se na svůj vlastní úkol, tedy komunikaci evangelia, jejím negativním důsledkem je určité zcírkevnění křestanství, jeho soustředěnost na sebe sama v podobě církve. Je tedy zřejmé, že vzniká napětí mezi církví, která se společnosti vzdaluje, a diakonií, která k ní ze své podstaty směřuje. Zároveň ovšem platí, že právě pro moderní západní křestanství uzavřené do sebe sama představuje diakonie ve veřejné sféře jedinečnou výzvu $\mathrm{k}$ hledání jeho nového zpř́tomnění a zviditelnění ve společnosti.

\section{Diakonie jako průnilk křestanství a sociální pomoci}

Již jsme zmínili Bártův výraz o adopci diakonie církví. V diskusi v českém evangelickém prostř̌edí se často používá obraz diakonie jako dcery církve - jako dítka, kterému církev dala život, kterým se ráda pochlubí, někdy mu také vyhubuje, protože se od ní nevděčně odvrací, nebo je respektuje jako již dospělou dceru, která si žije vlastním životem a se svou matkou udržuje víceméně zdvořilé vztahy. Otázkou ovšem je, zda tento obraz vztahu matky a dcery odpovídá realitě organizované diakonické práce $\mathrm{v}$ moderní společnosti a zda je možné ji relevantně popsat na základě teorie konstitutivních znaků, která diakonii chápe pouze jako sebeuskutečnění církve. Uvědomili jsme si přece, že diakonie v moderní době vlastně vzniká mimo církev, a to i díky př́lišnému zcírkevnění křestanství. Dnešní reálná diakonická práce participuje na systému sociální pomoci a není tak ovlivňována pouze svým náboženským zakotvením, ale zároveň musí zohledňovat kódy ostatních relevantních společenských systémů - vedle sociální práce například ekonomiky, práva či politiky.

Již v 70. letech 20. stol. rozlišoval Luhmann v rámci křestanství tři systémové reference: církev, diakonii a teologii. Církev jako systém duchovní komunikace plní vlastní funkci náboženství ve společnosti, diakonie představuje vztah $\mathrm{k}$ ostatním dílč́m systémům společnosti a je pro ni cha-

11 Srov. tamtéž, s. 317-318.

12 Tamtéž, s. 304-305.

13 Niklas LUHMANN, Gesellschaftsstruktur und Semantik, Band 3, Frankfurt am Main: Suhrkamp, 1989, s. 264.

14 Tamtéž.

15 Joachim MATTHES, Die Emigration der Kirche aus der Gesellschaft, Hamburg: Furche-Verlag, 1964.

16 Tamtéž, s. 14 
rakteristické, že řeší „zbytkové problémy“, které „jsou vytvořeny jinými systémy, ale nemohou být jimi ošetřeny". ${ }^{17}$ A teologii připadá úkol reflektovat církev i diakonii. Tento model koresponduje rovněž s biblickým významem pojmu diakonie, který - jak zdůraznil John N. Collins - klade důraz nikoli primárně na poníženou službu, nýbrž na službu v něčím zastoupení, službu zprostředkující. Diakonie tak ze své podstaty existuje „mezi světy“. Tvoří most mezi církví jako primárně liturgickým shromážděním a těmi, kdo jsou z různých důvodů vně. Reprezentuje křestanství ve veřejné sféře. Dává možnost participovat na Kristově vítězství nad zlem i těm, kdo se na jeho oslavě v daném společenství nemohou podílet liturgicky. ${ }^{18}$ Pro určení místa diakonie v moderní společnosti proto navrhuji grafické znázornění pomocí dvou částečně se překrývajících kružnic. Jednou z nich je systém sociální pomoci a druhou systém křestanství. Diakonie tvoří průnik těchto kružnic.

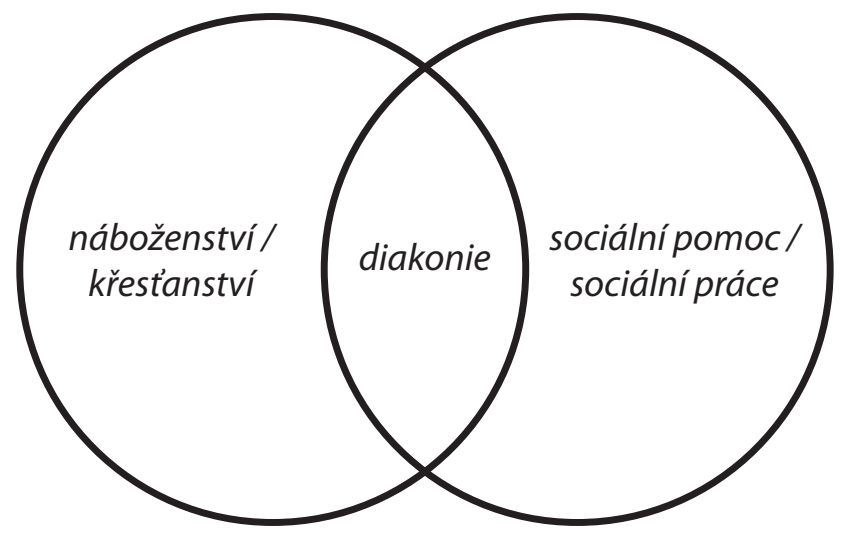

Grafické znázornění diakonie jako průniku systémů náboženství a sociální pomoci

\section{Závěrem: dialkonie jako sestra církve}

Zdá se, že vzhledem k historickému vývoji, dnešní situaci diakonie v rámci systému veřejných služeb i její teologické reflexi bude přiměřenější hovořit s Beate Hofmann o novodobém přijetí diakonie za „adoptivní sestru církve“, ${ }^{19}$ souputnici církve v systému křestanství, její „,sestru v Kristu“. Právě rozvolnění pouta mezi církví a institucionalizovanou diakonií může vést - a leckde již skutečně vede - $\mathrm{k}$ promýšlení diakonického charakteru a odpovědnosti samotných církevních společenství. Viděli jsme ovšem, že ruku v ruce s diferenciací církve a diakonie jde také úsilí o jejich hlubší sepětí. K postižení dnešní situace diakonie tak nepostačí jen aplikace sekularizační teze. Také v oblasti sociálních aktivit se uplatňuje vliv postsekularismu a deprivatizace náboženství. Funkcionální diferenciace sociálních systémů neodporuje možnosti jejich strukturálního znovuspojování - $\mathrm{s}$ vědomím vnitřní diferencovanosti a př́slušnosti $\mathrm{k}$ různým systémům. Navržený model diakonie jako průniku sociálních systémů křestanství a sociální pomoci znamená, že v křestansky orientované charitativní práci musí docházet k souběžnému aktivování kódů imanence/transcendence a pomáhat/ne-pomáhat, a klade tak nemalé nároky na ty, kdo se

17 Niklas LUHMANN, Funktion der Religion, Frankfurt am Main: Suhrkamp Verlag, 1977, s. 58.

18 Více viz Karel ŠIMR, Diakonie v perspektivě teorie sociálních systémů, s. 83.

19 Beate HOFMANN, Ekklesiologische Begründungsansätze von Diakonie, in: Helfendes Handeln im Spannungsfeld theologischer Begrundungsansätze, ed. Heinz RÜEGGER - Christoph SIGRIST, Zürich: Theologischer Verlag, 2014, s. 98. 
na dané praxi podílejí. Spojení sociální pomoci a křestanství v podobě duchovní komunikace nebo teologické reflexe problémů pomoci v dnešním světě ovšem představuje velmi zajímavou podobu prrítomnosti křestanství ve společnosti. Toto spojení se neuplatňuje jen ve vykonávání pastoračních aktivit či rozvoji teologické perspektivy v rámci mezioborové reflexe, ale také v hledání křestansky adekvátních podob managementu diakonických zařízení či rozvíjení diakonické spirituality pracovníků.

Skutečnost diakonie ve shora uvedeném smyslu představuje pozoruhodný „hybrid“ a svou dvojí loajalitou pochopitelně irituje jak církev, tak společnost. V diakonické práci dochází ke každodennímu setkávání nesourodých hermeneutik, které ovšem mủže být pro obě strany př́nosné: pro křestanství je mostem do sekularizované a církvi odcizené společnosti a pro sociální práci př́iležitostí k hledání zdrojů pro její základní hodnoty, jako je např. lidská důstojnost, aby se nestaly jen „nekrytými bankovkami“.

\title{
Diakonie ve veřejné sféře - dcera nebo sestra církve? Církev a diakonie mezi oddělením a přiblížením
}

\begin{abstract}
Abstrakt
Příspěvek se pokouší o lokalizaci soudobých rozvinutých podob organizovaných diakonických aktivit vzhledem k církvi a společnosti. Na základě historické, sociologické a teologické analýzy křestanského pomáhajícího jednání s ohledem na jeho vývoj v novověku artikuluje názor, že pro reflexi institucionalizované diakonie a charity $v$ moderní funkcionálně diferencované společnosti nedostačuje teorie konstitutivních znaků církve, chápající diakonii jako jeden z realizačních znaků církve, ale je přiměřenější ji popsat jako spojení systémů náboženství (křestanství) a sociální pomoci (sociální práce) - a tedy chápat ji nikoli jako dceru, nýbrž jako sestru církve. To na jedné straně přináśí potřebu komplexního mezioborového př́stupu k reflexi tohoto pozoruhodného "hybridu", na druhé straně to ovšem vyžaduje, aby pomáhající jednání v křest’anské perspektivě nerezignovalo ani na svou náboženskou kvalifikaci, která se má projevit např́klad v rozvoji křestanské kultury diakonických zařízení nebo diakonické spirituality jejich pracovníků.
\end{abstract}

Klíčová slova: diakonie, církev, sociální pomoc, teorie sociálních systémů

\author{
Kontakt na autora \\ Mgr. Karel Šimr \\ Jihočeská univerzita v Českých Budějovicích \\ Teologická fakulta, Katedra filosofie a religionistiky \\ Kněžská 8, 37001 České Budějovice \\ simrka00@tf.jcu.cz
}

